\title{
Host Resistance against Tumor and Cancer Autografts in Humans
}

\author{
Tsuguo Shikata \\ Department of Surgery (Prof. K. Kawamura), \\ Kyoto Prefectural University of Medicine, Kyoto
}

\begin{abstract}
In recent years, the outcome of tumor-growth has increasingly been interpreted from the tumor-host relationship. Some tumor-factors such as malignancy, antigenicity of tumor, etc., contribute to determining the relation. Our immunological research on experimental and human cancers revealed appearance of cancer antigen and loss of organ specific antigen in cancer tissues. Several host factors may also contribute to host resistance, such as hormonal regulation, reticuloendothelial activity, antibody titers, etc.

Among the above-mentioned factors, none can be independently indicative of the host resistance. The author's experience on cancer auto-transplantation shows that, although it does not promise a better prognosis, it is useful in the evaluation of the degree of relapse and metastasis of tumors in the abdominal cavity. The author believes that a safe and simple aid for the diagnosis of cancer relapse is offered by the auto-transplantation. Immunological aspect of tumors and its relationship to cancer auto-transplantation is also discussed.
\end{abstract}

Until recently cancer cells had been considered to be characterized by their autonomous growth and development from the pathological standpoint. As a consequence attention was directed solely to the degree of malignancy of the tumor cells, and tumor-bearing organisms were believed to offer no resistance against tumor growth., ${ }^{12}$ The organisms develop thus cachexia and finally succumb to the disease. It was generally accepted that slight interstitial reaction was the only sign of resistance on the side of the tumor-bearing host against the tumor, and even this reaction was apt to be regarded as an expression of malignancy of cancer. ${ }^{3.4}$ At present, however, there is no complete agreement as to the real nature of malignancy.

For the last seven years the author has investigated the antigenic specificity of cancer cells. From experimental and clinical observations, the author has come to the conclusion that the host is exerting an effect to resist tumor growth and development, and that the development of tumor depends on the host-tumor relationship. However, it is very difficult to express the resistance of the host by definite criteria, and all criteria in the past were complicated by numerous non-

Received for publication, December $26,1966$.

* Delivered at the 6th General Meeting of the Japan Society of the Reticuloendothelial System, April 24, 1966, Nagoya. 
specific reactions. ${ }^{5,6}$ Since our experiments with auto-transplants of cancer tissues have indicated a close correlation between the growth and development of auto-transplanted cancer cells and cancer cells pre-existing and growing in the host, we assume that the outcome of transplants can be used as one of the criteria indicating the interaction between the host and tumor. In the present experiments the author investigated the antigenicity of cancer cells in association with the resistance of the tumor-bearing host on the basis of cancer auto-transplantation. ${ }^{3}$ Its implications to the surgical and medical cancer treatment will be discussed.

\section{Methods And Results}

\section{Cancer Antigen}

In clinical pictures of malignant tumors, numerous types of growth and degrees of malignancy are observed. Pertinent studies of the antigenicity of tumor cells and the resistance of cancer-bearing hosts would be possible by the following approaches. First, the results of clinical experiences on the antigenicity of cancer tissues investigated by the use of the gel diffusion method and the fluorescent antibody technique will be reported.

As transplantable tumors, Ehrlich's ascitic tumor, Yoshida sarcoma, and rat ascites type hepatoma $\mathrm{AH} 130$ were used for the present investigation. A specific precipitation band was observed with the ascites of some mice grafted with Ehrlich's tumor when determined by Ouchterlony's method. In some rats with Yoshida sarcoma specific precipitation band of the plasma was observed in immunoelectrophoresis.

Cell fractionation of $\mathrm{AH} 130$ was performed and the antigenicity of each of the fractions was investigated by the indirect fluorescent antibody technique. The highest antigencity was found in the insoluble fraction; on the other hand, the highest specificity was found in the microsome fraction. The transplantable tumor thus contained antigens not existing in the original organ which had given rise to the tumor. However, because genetic differences are to be taken into consideration, we must be very careful in evaluating the tumor specificity of these antigens. By application of these experimental methods on human tumors, the following results were obtained. Upon analysis by Ouchterlony's method, some cancer tissues were found to have partly lost organ specific antigencity after removal of the common factor by absorption, but others showed gain or acquisition of antigenic factors which were not present in normal organs. Still in other cases, both gain and loss of antigens were ascertained, but the degree of reaction varied from case to case.

On the other hand, immunological behavior of cancer cells was examined by means of fluorescent antibody. Surgically removed stomachs in 9 cases of gastric cancer and 2 cases of gastric ulcer were used as antigen sources, Sliced 
Table 1. Antigen sources

\begin{tabular}{|c|c|c|c|c|c|}
\hline Case No. & Age & Sex & $\begin{array}{c}\text { Blood } \\
\text { type }\end{array}$ & Pathological diagnosis & $\begin{array}{l}\text { Procedure } \\
\text { of antigen* }\end{array}$ \\
\hline 1 & 64 & f & $A B$ & $\begin{array}{c}\text { Papillary adenocarcinoma } \\
\text { with liver metastasis }\end{array}$ & I \\
\hline 2 & 68 & $\delta$ & 0 & $\begin{array}{l}\text { Papillary tubuloadeno- } \\
\text { carcinoma }\end{array}$ & I \\
\hline 3 & 41 & $\hat{\sigma}$ & B & $\begin{array}{l}\text { Anaplastic infiltrating } \\
\text { carcinoma }\end{array}$ & I \\
\hline 4 & 58 & $\delta$ & B & Adenocarcinoma & I \\
\hline 5 & 68 & 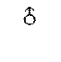 & $\mathrm{O}$ & $\begin{array}{l}\text { Tubuloadenocarcinoma } \\
\text { with liver metastasis }\end{array}$ & I \\
\hline 6 & 64 & q & 0 & $\begin{array}{l}\text { Poorly differenciated } \\
\text { carcinoma }\end{array}$ & I \\
\hline 7 & 69 & ? & B & Medullary carcinoma & II \\
\hline 8 & 25 & 우 & B & Anaplastic carcinoma & III \\
\hline 9 & 31 & $\delta$ & $\mathrm{O}$ & Peptic ulcer & I \\
\hline 10 & 40 & $\delta$ & $\mathrm{O}$ & Peptic ulcer & I \\
\hline 11 & 55 & $s$ & 0 & Adenocarcinoma & II \\
\hline
\end{tabular}

* See text

cancer tissues or non-cancerous gastric tissues were homogenized with a Waring blendor, centrifuged 30 minutes at $3,000 \mathrm{rpm}$ after freezing and thawing, and the supernatant was used as cancer or organ antigen (the I procedure of antigen preparation Table 1). The supernatant of the homogenates of cancer tissues or non-cancerous gastric tissues after centrifugation at $2,000 \times \mathrm{g}$ was used as a preparation of nuclear fraction (the II procedure of antigen preparation, Table 1). Another preparation of nuclear fraction was obtained from homogenates with a Potter-Elvehjem homogenizer (the III procedure of antigen preparation, Table 1).

At least two rabbits were immunized with each antigen specimen. The serum numbers of the animals which could be effectively immunized are given in Table 2, together with the method of immunization.

The staining was performed by means of direct and indirect methods, and the results were evaluated in reference to normal and cancer cells as well as to stromal components before and after absorption with specific sera, as are demonstrated in Table 3.

By staining with the fluorescent antibody technique, we could confirm a specific behavior in none of the cancer cells. In other words, the antigenicity of human cancer varied from case to case, and the result led to the conclusion that cancer specific antigens were very weak in nature, if they existed at all.

\section{Host Resistance}

For a long time, the attention of investigators has been engaged in the interstitial reaction of cancerous tissue, stromal reaction, the function of the reticuloendothelial system, hemopoietic activities, nutritional condition (or 
TABLE 2. Methods of immunization for rabbits

\begin{tabular}{|c|c|c|c|}
\hline $\begin{array}{l}\text { Case } \\
\text { No. }\end{array}$ & Antigen & Method of immunization & Antisera \\
\hline 1 & $\begin{array}{l}\text { Supernatant of gastric cancer } \\
\text { homogenate } \\
\text { Supernatant of normal stomach } \\
\text { homogenate } \\
\text { Supernatant of metastatic liver } \\
\text { homogenate } \\
\text { Supernatant of metastatic liver } \\
\text { homogenate }\end{array}$ & $\begin{array}{l}\text { Incomplete Freund adjuvant } 40 \\
\mathrm{mg} / 2 \mathrm{w} .5 \text { times } 5 \mathrm{mg} \text { booster }\end{array}$ & $\begin{array}{l}1 \mathrm{~A} \\
\mathrm{1B} \\
\mathrm{1C} \\
\mathrm{ID}\end{array}$ \\
\hline 2 & $\begin{array}{l}\text { Supernatant of gastric cancer } \\
\text { homogenate } \\
\text { Supernatant of normal stomach } \\
\text { homogenate }\end{array}$ & $\begin{array}{c}\text { Alum adjuvant } 40 \mathrm{mg} / 1 \mathrm{w} .5 \\
\text { times } 10 \mathrm{mg} \text { booster }\end{array}$ & $\begin{array}{l}2 \mathrm{~A} \\
2 \mathrm{~B}\end{array}$ \\
\hline 3 & Supernatant of gastric cancer & $\begin{array}{l}\text { Incomplete Freund adjuvant } 50 \\
\mathrm{mg} / 1 \mathrm{w} .5 \text { times } 5 \mathrm{mg} \text { booster }\end{array}$ & 3 \\
\hline 4 & Supernatant of gastric cancer & $\begin{array}{l}\text { Alum adjuvant } 20 \mathrm{mg} / 1 \mathrm{w} .7 \\
\text { times } 5 \mathrm{mg} \text { booster }\end{array}$ & 4 \\
\hline 5 & $\begin{array}{l}\text { Supernatant of gastric cancer } \\
\text { homogenate }\end{array}$ & $\begin{array}{l}\text { Alum adjuvant } 50 \mathrm{mg} / \mathrm{lw} .7 \\
\text { times } 10 \mathrm{mg} \text { booster }\end{array}$ & 5 \\
\hline 6 & $\begin{array}{l}\text { Supernatant of metastatic } \\
\text { lymph-node homogenate }\end{array}$ & $\begin{array}{l}\text { Incomplete Freund adjuvant } 40 \\
\mathrm{mg} / \mathrm{lw} .40 \mathrm{mg} \text { booster }\end{array}$ & 6 \\
\hline 7 & $\begin{array}{l}\text { Nuclear fraction of cancer } \\
\text { (Waring blendor) }\end{array}$ & $\begin{array}{l}\text { Incomplete Freund adjuvant } 50 \\
\mathrm{mg} \times 2 / 1 \mathrm{w} .14 \text { times } 10 \mathrm{mg} \\
\text { booster }\end{array}$ & 7 \\
\hline 8 & $\begin{array}{l}\text { Nuclear fraction of cancer } \\
\text { (Potter) }\end{array}$ & $\begin{array}{l}\text { Incomplete Freund adjuvant } 50 \\
\mathrm{mg} \times 2 / 1 \mathrm{w} .10 \text { times } 10 \mathrm{mg} \\
\text { booster }\end{array}$ & 8 \\
\hline 9 & $\begin{array}{l}\text { Supernatant of normal portion } \\
\text { of gastric ulcer homogenate }\end{array}$ & $\begin{array}{l}\text { Alum adjuvant } 40 \mathrm{mg} / \mathrm{lw} .5 \\
\text { times } 10 \mathrm{mg} \text { booster }\end{array}$ & 9 \\
\hline 10 & $"$ & $"$ & 10 \\
\hline 11 & $\begin{array}{l}\text { Nuclear fraction of cancer } \\
\text { (Waring blendor) }\end{array}$ & $\begin{array}{l}\text { Incomplete Freund adjuvant } 50 \\
\mathrm{mg} \times 2 / 1 \mathrm{w} .10 \text { times } 5 \mathrm{mg} \\
\text { booster }\end{array}$ & 11 \\
\hline
\end{tabular}

factors), hormonal activities, enzymatic activities, antibody formation, serum antibody, cellular antibody, graft-rejection and delayed hypersensitivities. ${ }^{3,7,1}$ The reticuloendothelial system is concerned with the resistance against cancerous tissues, and there is reported that the stimulation of the reticuloendothelial system may enable the host to increase its resistance against cancer. ${ }^{9}$

The hemopoietic capacity and the nutritional condition belong to nonspecific resistance of the host and may have some correlation with the progress of cancer growth. In connection with the treatment of cancer, particularly with tumors of the reproductive organs, specific suppression of tumor growth by 
TABLE 3. Results of the staining with fluorescent antibody method

\begin{tabular}{|c|c|c|c|c|c|c|c|c|}
\hline \multirow[b]{2}{*}{$\begin{array}{c}\text { Case } \\
\text { No. }\end{array}$} & \multirow[b]{2}{*}{ Age } & \multirow[b]{2}{*}{ Antisera } & \multicolumn{2}{|c|}{ Normal cell } & \multicolumn{2}{|c|}{ Cancer cell } & \multicolumn{2}{|c|}{ Stroma } \\
\hline & & & $\begin{array}{c}\text { Before } \\
\text { absorp- } \\
\text { tion }\end{array}$ & $\begin{array}{l}\text { After } \\
\text { absorp- } \\
\text { tion }\end{array}$ & $\begin{array}{l}\text { Before } \\
\text { absorp } \\
\text { tion }\end{array}$ & $\begin{array}{l}\text { After } \\
\text { absorp- } \\
\text { tion }\end{array}$ & $\begin{array}{c}\text { Before } \\
\text { absorp- } \\
\text { tion }\end{array}$ & $\begin{array}{l}\text { After } \\
\text { absorp- } \\
\text { tion }\end{array}$ \\
\hline 1 & 64 & $\begin{array}{l}1 \mathrm{C} \\
1 \mathrm{D} \\
8 \\
11\end{array}$ & $\begin{array}{l}+ \\
+ \\
+ \\
+\end{array}$ & $\begin{array}{l} \pm \\
+ \\
\pm \\
+\end{array}$ & $\begin{array}{l}+ \\
+ \\
H \\
H\end{array}$ & $\begin{array}{l}+ \\
\pm \\
+ \\
+\end{array}$ & $\begin{array}{l} \pm \\
+ \\
\pm \\
\pm\end{array}$ & $\begin{array}{l}- \\
+ \\
\pm \\
\pm\end{array}$ \\
\hline 2 & 68 & $\begin{array}{l}2 \mathrm{~A} \\
2 \mathrm{~B}\end{array}$ & - & - & - & - & $\begin{array}{l} \pm \\
\pm\end{array}$ & $\begin{array}{l} \pm \\
\pm\end{array}$ \\
\hline 3 & 41 & 3 & + & \pm & \pm & \pm & - & - \\
\hline 4 & 58 & 4 & + & \pm & - & - & \pm & - \\
\hline 5 & 68 & 5 & - & - & - & - & - & - \\
\hline 6 & 64 & 6 & - & - & - & - & - & - \\
\hline 7 & 69 & $\begin{array}{r}7 \\
8 \\
11\end{array}$ & $\begin{array}{l}+ \\
+ \\
+\end{array}$ & $\begin{array}{l}- \\
\pm \\
-\end{array}$ & $\begin{array}{l}- \\
+ \\
+\end{array}$ & $\begin{array}{l}- \\
+ \\
-\end{array}$ & $\begin{array}{l} \pm \\
+ \\
\pm\end{array}$ & $\begin{array}{l}- \\
\pm \\
-\end{array}$ \\
\hline 8 & 25 & $\begin{array}{r}8 \\
11\end{array}$ & $\begin{array}{l}H \\
+\end{array}$ & - & $\begin{array}{l}H \\
\pm\end{array}$ & - & $\begin{array}{l}+ \\
+\end{array}$ & \pm \\
\hline 11 & 55 & $\begin{array}{l}11 \\
8 \\
7 \\
1 \mathrm{C} \\
1 \mathrm{D}\end{array}$ & $\begin{array}{l}+ \\
+ \\
- \\
- \\
-\end{array}$ & $\begin{array}{l}- \\
- \\
- \\
-\end{array}$ & $\begin{array}{l}+ \\
+ \\
- \\
- \\
-\end{array}$ & $\begin{array}{l}- \\
- \\
- \\
-\end{array}$ & $\begin{array}{l}+ \\
+ \\
\pm \\
\pm \\
H\end{array}$ & $\begin{array}{l}- \\
\pm \\
- \\
- \\
+\end{array}$ \\
\hline
\end{tabular}

hormones is observed, and this is one of the evidences that some cancer suppressive action can be displayed by the host.

Lately, a great deal of attention has been focused on the changes in the enzymes of cancer patients, but it is rather appropriate to regard these as changes secondary to cancerization. Many reports are available on lowered antibody production in cancer-bearing animals. ${ }^{1-4,10,11}$

A cancer antigen, if present, is extremely difficult to demonstrate on account of its very weak serological reactivity. Using one of the very sensitive reactions, that is, Boyden's hemagglutinating reaction, we investigated changes of serum antibody titers of cancer patients against cancer homogenates. This hemagglutinating antibody titer was maintained at a fixed level in those patients who survived relatively long terms, but it fell abruptly in cases of early postoperative death. In some recent reports a participation of cellular immunity in determining the clinical course of cancer patients is presumed on the basis of a certain correlation between reactive cell infiltration into cancer tissues and the 
survival time of the patient. On the contrary, a number of investigators assume a lowered host resistance of cancer patients, because the skin homograft is retained two or three times longer in cancer patients than in healthy subjects.

Furthermore, reports of high incidences of negative tuberculin tests in cancer patients are published. According to the author's result, negative tuberculin reaction was seen in 20 per cent of normal humans and 58 per cent of cancer patients. In the stage of localized tumors, the tuberculin test was negative in 50 per cent; whereas in patients in the terminal stage of cancer this rate was 55 per cent, there being little difference in the rate. However, it is difficult to discuss delayed hypersensitivity on the basis of the tuberculin test alone. Although we can presume various factors involved in the resistance of the host, we must be at the same time aware of the possibility that these factors exert their influences in a complex manner on account of their combinations. One cannot always pinpoint any one factor as representing the resistance of the host. Observations on the development of the cancerous tissue and the manner in which autotransplants are 'taken' in the recipient reveal that a definite relationship exists between the development of grafts and the prognosis of the patient. We accept that the autograft method may serve to supply an index expressing the balance of resistance in the tumor-host relationship. In view of the difficulty in foreseeing the outcome of cancer patients either from the host's condition or on the finding of the tumor itself, the authors have been performing auto-transplants of human cancer for the past few years to evaluate the prognosis of cancer patients.

\section{Auto-transplantation}

Auto-transplantation is a simple and safe procedure for any surgeon. We believe we are able to understand to a certain extent the resistance of the host from the behavior of the auto-transplanted slices. The following relates the author's experiences in auto-transplantations with some comments.

Our method of auto-transplantation was as follows: A slice of the tumor was obtained aseptically. If this was impossible, a portion of the metastatic lesion was resected. Tumor slices were prepared in a size of $3 \mathrm{~mm} \times 3 \mathrm{~mm} \times 1 \mathrm{~mm}$, and 3 to 6 slices were transplanted in the subcutaneous tissue of the abdominal wall of the respective patient. The transplanted slices were palpated daily, and if the slices attained the size of a pea, the result was regarded as 'take' (cf. Fig. 1). The behavior of the grafts was variable, some of the grafts started to grow after about 2 weeks, while others exhibited the sign of 'take' only after several months. The transplant was encapsulated by strong connective tissue and tumor infiltration or metastasis to the surrounding tissue was observed in none of the cases. This result demonstrates that the auto-transplantation of cancer is harmless. The time required for the graft to be recognized as 'take' was variable, and one must not overlook the fact that there were cases where a graft which temporarily seemed to show regression in growth thereafter was recognized as 'take' 10 


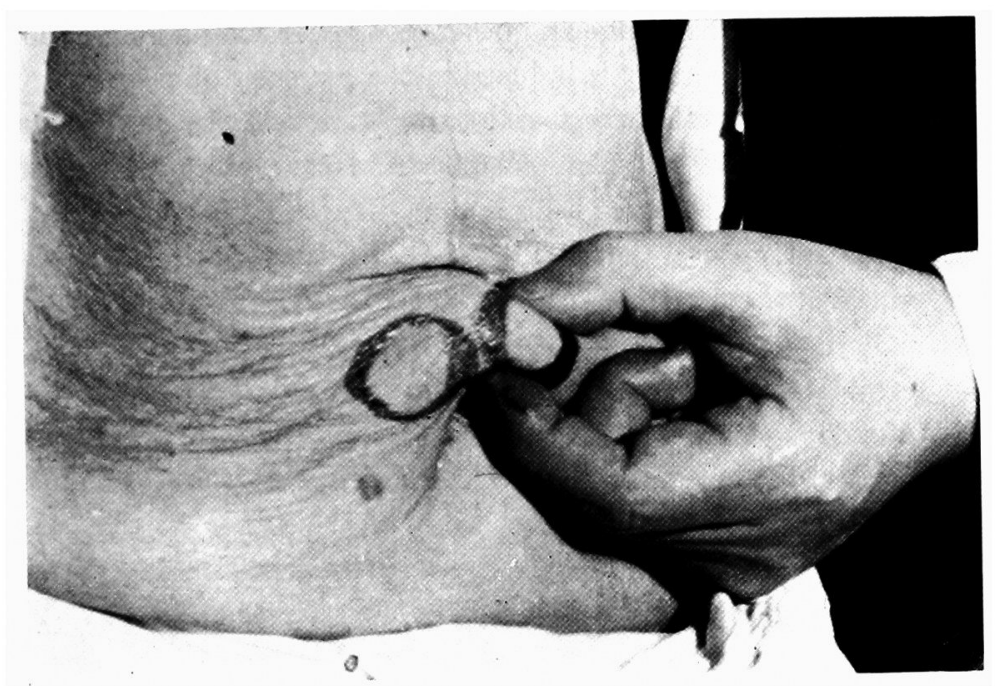

Fig. 1. Auto-transplantation of cancer tissue in the abdominal wall. The transplanted slices attained the size of a pea, which was regarded as 'take'.

to 18 months after transplantation. Of the group which took grafts within 6 months after transplantation, practically all the cases died within 3 months from the date of 'take'. In other words, it was likely that the resistance had been lowered considerably after the first operation against the tumor. Autopsies on these cases showed that most of the deaths occurred under peritonitis due to cancer dissemination. In the majority of the patients who 'took' after 6 months, the take of the graft became perceptible only after 10 months. At this stage subjective symptoms were found in none of the cases, although there were a few cases of recurrence as confirmed from the local symptoms and clinical examinations. Most of them died within 3 months after the grafts were taken.

of all the cases thus examined an analysis of the antigen was performed by the gel diffusion method on 20 cases in which tumors could be resected. From the analysis, it was found that in the group of 'take' in the early stages normal organ antigens was partly lost in cancerous tissues. On the other hand, in the group which failed to take the grafts, most of the tumors had antigens which were not found in normal tissues. Gain or loss of cancer antigens is a complex problem, and strictly speaking, it is impossible to say that the cancerous tissue has simply gained or lost antigenicity. In 35 per cent of the cases, a loss of tumor antigenicity was confirmed, and most of them took the graft in the early stages after transplantation. In 15 per cent of the cases in which antigenic gain was confirmed, a delay in the 'take' of the graft was observed. In the remaining 50 per cent of the cases both gain and loss of the antigenicity were confirmed. In the majority of the cases there was a partial loss of normal organ specific antigen and at the same time a gain in antigenicity of cancer tissue anew; but even out of these 
cases some took grafts at early stage and others took only after a long period. One can say that a loss of antigenicity is induced in the majority of cases where tumors can be removed and the grafts are found to be taken in the early stage of the grafting. If one interprets the phenomenon from the standpoint of the host's resistance, one must first deal with the problem of serum antibody. Of the cases which took in the early stage, the aggultination titers dropped in a short period, but the agglutination titers of those cases which failed to take were maintained at a high level.

In the terminal stage of cancer patients a considerable rise in 'Congo-red index' was observed as compared with the normal subjects. Comparison between the cases of positive and negative 'take' of grafts revealed no difference in the index. It was impossible to predict the 'take' of the grafts on the basis of the index of recipients. It is questionable whether decreased functional capacity of the reticuloendothelial system is responsible for decreased host's resistance against cancer. In numerous cases, however, it was possible to suspect postoperative recurrence and metastasis in the peritoneal cavity from the behavior and development of the auto-transplants of cancer. From these observations the author believes that the behavior of the auto-transplants of cancer can be used as an important index for the diagnosis of the recurrence of cancer and the prognosis of the patient.

\section{Recurrence and Its Correlations with Cancer Autografts}

For an early detection of recurrences and metastases of cancer after the first operation against tumor, we regarded the behavior of the cancer autotransplants as one of the useful indices.

The recurrence and metastasis of cancer after the first operation against tumor depend on the progress of the cancer growth, which is determined not only by the degree of its malignancy, but also by postoperative treatments. Consequently, it is usually a much more complex problem than the detection of the original cancer. In this respect we assume that the auto-transplants of cancer may serve as a useful method, because the cancer cells of the autograft and those in the body persisting after the operation are in the same phase of their development.

In association with the results of autograft transplantation, the author's experiences of interesting cases are presented as follows.

In the first case, a 59-year-old male complained of nausea and vomiting and suffered from anemia ten months after the operation against gastric cancer. The patient had severe hematemesis, and a hard tumor of the size of a fist was palpable in the abdominal region. Although cancer autograft of this patient did not show any sign of 'take', cancer recurrence was diagnosed on the basis of clinical symptoms and laboratory examinations. The patient died without further operative intervention, because the patient's condition had appeared hopeless on account of presumed cancer recurrence. At necropsy, however, no cancer recurrence was confirmed, and the cause of death was 
intestinal intussusception at the site of Braun's anastomosis.

The second case was that of a 67-year-old woman who was operated on against gastric cancer with liver metastasis. Gastric resection and partial lobectomy of the right lobe of the liver were performed, and tumor tissues were obtained for autografts. The patient visited the hosptial a year and 2 months after operation, and the autografts were found to be the size of a pea. She had no manifest clinical symptoms, and no significant changes in laboratory findings. The patient did not consent to further operations at that time, but 2 months later she agreed to operative treatment. A large metastatic tumor in a lymph node was found, but recurrence of the cancer was not observed in the liver or at the site of the anastomosis. The metastatic tumor was removed and the patient is in a good condition up to the present.

The third case is that of a 51 -year-old male who was operated on for gastric cancer. Gastrectomy was performed and tumor specimens for autograft were taken. The patient visited the hosptial again with complaints of anorexia three months later. The graft had attained the size of a pea at that time. Reoperation was performed and no tumor was found at the site of the anastomosis or the residual stomach, but disseminated metastatic cancerous lesions were found in the mesentery.

\section{Discussion}

The probability for successful radical surgical management of relapsing gastric cancer is very low. On account of the complexity of pathologic features of gastric cancer, not all the cases of relapsing gastric cancer belong to the indication of surgery. But, in some types of relapse of gastric cancer, radical operation can be fully successfully, only if the indications are adequately decided. Such local relapse as in the stump area of the residual stomach (mostly in the area of anastomosis) or in the regional lymph nodes may be regarded as indicative of feasible reinstitution of radical operation. When the relapse in the residual stomach causes a stenosis of the anastomosed area, which admits of relatively easy clinical diagnosis, the case can be subjected to radical reoperation. Remote metastasis, mainly in the peritoneum, excludes of course the possibility of radical reoperation. In these instances, the initial operation against cancer has to be reinforced by other treatments including the use of anti-cancer agents. Even if surgical operations are carried out with great care, the presence of factors more or less beyond control such as cancer cells in the blood stream may complicate the postoperative course of cancer patients. Biological relationship between the host and cancer cells influences also the prognosis.

A problem which demands an especially meticulous approach is the relapse in the regional lymph nodes. Clinical diagnosis of this condition is very difficult. If not discovered in time, extensive lymph-node metastasis and remote metastasis develop and frustrate the effort of repeated radical operations. ${ }^{7}$ In view of such clinical courses where cancer relapse is difficult to demonstrate by conventional clinical and laboratory examinations, we have suggested the use of autotransplant graft as a useful indicator.

The probability of success from radical reoperation is generally believed to be low in the cases of relapse within short periods after the first operation. 
Even in the cases in which the finding at the first operation does not indicate an unfavorable outcome, early relapse or metastasis is often encountered. ${ }^{12-14}$ The variable postoperative course is again an expression of complex factors including the speed of cancer development and the host resistance. This will make an immunological approach to cancer all the more important. Immunological examination of cancer specimens obtained at operation reveals in most of the cases the results suggestive of partial loss of the organ specific antigenicity of the normal tissue and the gain of a new cancer-specific antigen. The intensity of the shift of antigenicity varies with cases. Also, some cases exhibited only the above-mentioned loss, while other cases demonstrated only the gain.

In human cancers it is practically impossible to sample the cancer tissues for antigenic analysis at arbitrary different stages of cancer development. An evaluation of cancer development, however, is made possible on the basis of the observations on the cancer auto-transplant in the manner we have suggested, since the growth of the auto-transplant is influenced by cancer antigenicity.

The cells of every organ have organ specific protein. Consequently, ectopic transplantation of cells from an organ is unsuccessful even in one and the same host. Since a cancer cell originates from the normal cell of a certain organ, the cancer cell cannot either be an exception to the above rule. The possibility of metastasis may be ascribed probably to the masking of the cell-specific protein. At the same time, the cancer cell may lose partly or wholly the antigenicity of its normal mother cell, comes to acquire a new antigenicity, and thus makes its ectopic growth possible. Furthermore, from the theory of acquired tolerance, what can function as the antigen of auto-antibody must be limited to the substances biosynthesized in and after the embryonic stage or to the substances in the organs which do not come into contact with the antibody forming tissues.

The cancer cell which has undergone such changes as above may be regarded as being able to stimulate antibody formation. On the other hand, there is the following possibility: a cancer cell with organ specificity that has migrated to a different area of the body and starts ectopic growth is dealt with by the surrounding cells as 'not self'. It stimulates the antibody forming cells and induces the development of auto-immunity. Occasional clinical experiences of sudden interruption of metastasis formation will support the above view.

Another clinical experience which deserves attention is that metastatic cancers, like transplanted cancers in experimental animals, respond well to chemotherapies, which prove to be hardly effective on the primary tumors. This may be interpreted as follows. The tumor cells in metastatic foci have lost a part of the antigen of the organs from which they took their origin; the above-mentioned loss of antigenicity favors the extrication of the tumor cells from the original organ where they have developed, and opens the way to tumor metastasis. The tumor cells which have established their growth in other organs develop their own antigenicity. The tumor cells are at first dealt with as 'not self' by the tissue to 
which they have metastasized. During this period the reticuloendothelial functions of the host are practically normal, and the formation of some antibodies brings about a state of antagonism (auto-immunity). At the same time, the behavior of the auto-transplanted cancer graft, which is dealt with as 'not self', is characterized by necrosis.

While the cancer cells are in such a state, chemotherapeutic agents are expected to be effective. The chemotherapeutic agents will, on the contrary, hardly exert their influence upon the original tumor that has not yet acquired much tumor-specific antigenicity, especially when the tumor shows only loss and no gain in its antigenicity. When cancer progresses and proliferates, it gradually affects the reticuloendothelial system. During this process, the antigen becomes excessive, resulting in the inhibition of antibody formation. As a consequence, the cancer becomes more proliferative. At this stage, the transplanted cancer auto-graft may be regarded as 'self', and consequently it 'takes'.

Even though the results of our auto-transplantations of cancer have indicated the possibility or obtaining auto-immunity to cancer cells, the production of antibodies was not observed to such an extent as to inhibit the growth of the original cancer. However, there has been noted a parallelism between the establishment of the transplanted graft and the growth of the original cancer tissues. In this respect, our method is useful in early detection of cancer recurrence, when the patients are instructed to palpate the transplants and to present themselves to medical examination in cases of growing transplants.

\section{Conclusions}

1) The rate of cure of gastric cancer will rise through an early diagnosis of relapse after surgical operations and by means of the so-called second look operations.

2) Auto-transplantation of cancer does not promise an improvement of clinical course but is useful in evaluating the prognosis of cancer patients. The behavior of the transplanted tumor tissue provides reliable information about cancer recurrence and metastasis in the abdominal cavity.

3) An early diagnosis of relapse of gastric cancer is otherwise very difficult. In this respect, the auto-transplantation of cancer offers a safe and simple, but useful diagnostic aid.

4) The observation of the auto-transplanted graft has led to the conclusion that the antigenicity of gastric cancer is not constant, but varies according to the stages of cancer growth even in one and the same subject. 


\section{References}

1) Fisher, E.R. \& Turbull, R.B., Jr. Cytologic demonstration and significance of tumor cells in mesenteric venous blood in patients with colorectal carcinoma. Surg. Gynec. Obstet., 1955, 100, 102-108.

2) Engell, H.C. Cancer cells in circulationg blood; clinical study on occurrence of cancer cells in peripheral blood and in venous blood draining tumour area at operation. Acta chir. scand., Suppl., 1955, 201, 1-70.

3) Southam, C.M. \& Brunschwig, A. Quantitative studies of autotransplantation of human cancer. Cancer (Philad.), 1961, 14, 971-978.

4) Spjut, H.J., Hendrix, V.J., Ramirez, G.A. \& Roper, C.L. Cancer cells in pleural cavity washings. Cancer, 1958, 11, 1222-1225.

5) Moore, A.E., Sabachewsky, L. \& Toolan, H.W. Culture characteristics of 4 permanent lines of human cancer cells. Cancer Res., 1955, 15, 598-602.

6) Moore, G.E., Sandberg, A., \& Schubarg, J.R. Clinical and experimental observations of occurrence and fate of tumor cells in blood stream. Ann. Surg., 1957, 146, 580 587, disc. 593-595.

7) Puck, T.T. \& Marcus, P.I. Rapid method for viable cell titration and clone production with HeLa cells in tissue culture; use of X-irradiated cells to supply conditioning factors. Proc. nat. Acad. Sci. USA, 1955, 41, 432-437.

8) Roberts, S., Waten, A., McGrath. R., McGrew, E. \& Cole, W.H. Technique and results of isolation of cancer cells from eirculating blood. Arch. Surg., 1958, 76, 334-346.

9) Cole, W.H., Roberts, S., Waten, A., McDonald, G. \& McGrew, E. Dissemination of cancer cells. Bull. New York Acad. Med., 1958, 34, 163-183.

10) Sandberg, A.A., Moore, G.E., Crosswhite, L.H. \& Schubarg, J.E. Frequency of tumor cells in bone marrow and blood. Cancer. 1958, 11, 1180-1186.

11) Pool, E.H. \& Dunlop, G.R. Cancer cells in blood stream. Amer. J. Cancer, 1934, 21, 99-102.

12) Pruitt, J.C., Hilberg, A.W. \& Kaiser, R.F. Malignant cells in peripheral blood. New Engl. J. Med., 1958, 259, 1161-1164.

13) Waten, A.L., Moore, G.R. \& Hatiboglu, I. Cancer cells in thoracic duct lymph. Proc. Amer. Ass. Cancer Res., 1959-1960, 3, 72.

14) Seal, S.H. Silicon flotation; simple quantitative method for isolation of free. floating cancer cells from blood. Cancer $1959,12,590-595$. 